\title{
EFFECT OF DIETARY INCLUSION OF PALM OIL ON FEED CONSUMPTION, GROWTH PERFORMANCE AND PROFITABILITY OF BROILER
}

\author{
M. S. Rahman, M. A. Akbar, K. M. S. Islam, A. Iqbal and M. Assaduzzaman
}

\begin{abstract}
A total of 300 day-old Hubbard Classic broiler chicks were reared to investigate the effect of dietary inclusion of 2, 3, 4 and $5 \%$ of palm oil on feed consumption, growth performance and profitability of broiler. Addition of $4 \%$ palm oil in diet found to attribute additive effect on the growth of the bird from $2^{\text {nd }}$ to $4^{\text {th }}$ week of the trial. Broilers of 2 and 3\% oil added group attained 1791g and 1777.67g live weight, respectively which was $4 \%$ and $3 \%$ higher than that of the control. Similar effect of different levels of palm oil was also observed in case of live weight gain. Dietary inclusion of palm oil improved feed consumption and significantly $(\mathrm{P}<0.05)$ higher feed consumption was recorded in $4 \%$ palm oil group than $5 \%$ oil group. From the economic analysis on production cost of broiler, it was found that total cost per broiler was the lowest in control group (Tk. 115.92), which was lower by Tk. 8.23, 7.46, 9.13 and 2.68 than the $2 \%, 3 \%, 4 \%$ and $5 \%$ oil added groups, respectively. Profit earned from each group ( $\mathrm{Tk} / \mathrm{broiler}$ and $\mathrm{Tk} / \mathrm{kg}$ broiler) was statistically similar $(\mathrm{P}>0.05)$. It can be concluded that profitable broiler production might be possible without supplementation of palm oil.
\end{abstract}

Key words: Broiler, Feed Consumption, Growth, Palm oil, Profitability

\section{Introduction}

Poultry feeding is one of the most important aspects of poultry production because feed cost alone accounts for $65-75 \%$ of the total cost of egg and meat production (McNab, 1999). Therefore, for profitable poultry rearing, provision of economical and balanced feed is a must. Use of fats for animal feed has many advantages. It is the major source of increasing the energy content of diets. Addition of fat in broiler diet also provides increased growth rate, increased feed efficiency, decreased feed intake, linoleic acid, low dustiness of feeds, increased rate of gain which leads to decrease age at market and helps minimize heat increment during heat stress. In Bangladesh, soybean oil is generally used in feed mills to increase energy level especially in broiler diet, which results in high feed price.

Palm oil is rich in saturated fatty acid. The use of palm oil in broiler diets is attractive, because it is a saturated source that may be associated with a positive influence on meat

Department of Animal Nutrition, Bangladesh Agricultural University, Mymensingh-2202, Bangladesh

(Received: October 19, 2010) 
Bang. J. Anim. Sci. 2010, 39(1\&2)

firmness (Renner and Hill, 1991). Palm oil is relatively cheaper compared to other imported fats and it possesses many good qualities including more vitamin E (antioxidant) content, which makes it more stable (Pesti et al., 2002).

Very little information is available on the use of palm oil as a source of energy for improving growth performance of broilers and whether or not it could be used beneficially than other source of energy. Moreover, inclusion level of palm oil in broiler diet is not definitely known. Therefore, the current study was undertaken to investigate the effect of dietary supplementation of palm oil at different levels on feed consumption and growth performance of broilers and to determine the inclusion level and profitability of using palm oil in broiler diets.

\section{Materials and Methods}

The experiment was conducted with 300 day-old broiler chicks (Hubbard Classic) for a period of 35 days in the Animal Nutrition Field Laboratory, Bangladesh Agricultural University, Mymensingh. It was conducted in a Completely Randomized Design (CRD). Chicks were randomly distributed to 5 treatment groups each having 3 replications. There were 20 chicks in each replication. The treatment groups were given either $0,2,3,4$ or $5 \%$ of palm oil in feed.

Locally available feel ingredients (Table 1) were used to formulate ration for the broilers. The diets were prepared by hand mixing. Major ingredients were first thoroughly mixed, then the micro-ingredients were added. The diets were prepared with 4 different levels of palm oil $\left(\mathrm{T}_{1}=2 \%, \mathrm{~T}_{2}=3 \%, \mathrm{~T}_{3}=4 \%\right.$ and $\left.\mathrm{T}_{4}=5 \%\right)$ and at the same time a control diet $\left(\mathrm{T}_{0}\right.$ $=0 \%$ ) was also prepared. Starter diet and Finisher diet were supplied to the broilers for first 2 weeks and further 3 weeks, respectively. The nutrient requirement of the bird was satisfied according to BSTI standard.

The chicks were reared in cages for an experimental period of 35 days. The floor, wall and cages were cleaned and disinfected thoroughly. Chicks were brooded properly for 7 days with optimum temperature and lighting. Feed and water supply was ad libitum. Saw dust was used as litter during rearing. The birds were vaccinated against Newcastle disease (Ranikhet) and Infectious Bursal Disease (Gumboro). Strict bio-security measures were ensured during the experimental period. Records were kept of live weight, feed consumption and cost of ingredients, which were further used to calculate the growth performance and profitability. Data were analyzed by statistical computer programme MSTAT-C to compare the means of all parameter. 
Table 1. Composition of starter ration ( 0 - 2 weeks)

\begin{tabular}{|l|c|c|c|c|c|}
\hline \multicolumn{1}{|c|}{ Ingredients (kg) } & \multicolumn{5}{c|}{ Treatments $^{\#}$} \\
\cline { 2 - 6 } & $\mathbf{T}_{\mathbf{0}}$ & $\mathbf{T}_{\mathbf{1}}$ & $\mathbf{T}_{\mathbf{2}}$ & $\mathbf{T}_{\mathbf{3}}$ & $\mathbf{T}_{\mathbf{4}}$ \\
\hline Maize & 63.20 & 63.30 & 60.20 & 57.25 & 52.00 \\
Rice polish & 2.02 & 1.22 & 2.02 & 2.77 & 6.37 \\
Palm oil & 0.00 & 2.00 & 3.00 & 4.00 & 5.00 \\
Soybean meal & 29.50 & 25.80 & 29.50 & 31.25 & 30.90 \\
Protein concentrate & 2.75 & 5.25 & 2.75 & 0.00 & 0.00 \\
Meat \& bone meal & 0.50 & 0.50 & 0.50 & 2.50 & 3.00 \\
Lime stone & 0.80 & 0.70 & 0.80 & 1.00 & 1.50 \\
Dicalcium phosphate & 0.50 & 0.50 & 0.50 & 0.50 & 0.50 \\
L-Lysine & 0.05 & 0.05 & 0.05 & 0.05 & 0.05 \\
DL Methionine & 0.16 & 0.16 & 0.16 & 0.16 & 0.16 \\
Vit-min premix & 0.25 & 0.25 & 0.25 & 0.25 & 0.25 \\
Coccidiostat & 0.02 & 0.02 & 0.02 & 0.02 & 0.02 \\
Common salt & 0.25 & 0.25 & 0.25 & 0.25 & 0.25 \\
\hline Total & 100 & 100 & 100 & 100 & 100 \\
\hline Estimated nutrient composition & \multicolumn{7}{c}{. } & & & \\
ME (kcal/kg) & 2902.57 & 3021.12 & 3022.30 & 3018.05 & 3023.00 \\
CP (\%) & 21.25 & 20.99 & 20.97 & 21.00 & 21.06 \\
EE (\%) & 2.93 & 2.94 & 2.85 & 2.93 & 3.39 \\
\hline
\end{tabular}

${ }^{\#} \mathrm{~T}_{\mathrm{o}}=0 \%$ palm oil, $\mathrm{T}_{1}=2 \%$ palm oil, $\mathrm{T}_{2}=3 \%$ palm oil, $\mathrm{T}_{3}=4 \%$ palm oil and $\mathrm{T}_{4}=5 \%$ palm oil, included feed

Table 2. Composition of finisher ration ( 2 - 5 weeks)

\begin{tabular}{|l|c|c|c|c|c|}
\hline \multirow{2}{*}{ Ingredients } & \multicolumn{5}{c|}{ Treatments $^{\#}$} \\
\cline { 2 - 6 } & $\mathbf{T}_{\mathbf{0}}$ & $\mathbf{T}_{\mathbf{1}}$ & $\mathbf{T}_{\mathbf{2}}$ & $\mathbf{T}_{\mathbf{3}}$ & $\mathbf{T}_{\mathbf{4}}$ \\
\hline Maize & 65.60 & 66.50 & 62.60 & 59.50 & 57.00 \\
Rice polish & 2.27 & 1.00 & 2.27 & 3.27 & 4.27 \\
Palm oil & 0.00 & 2.00 & 3.00 & 4.00 & 5.00 \\
Soybean meal & 26.00 & 23.37 & 26.00 & 27.50 & 27.50 \\
Protein concentrate & 3.50 & 5.00 & 3.50 & 2.50 & 0.00 \\
Meat \& bone meal & 0.50 & 0.50 & 0.50 & 0.50 & 4.00 \\
Lime stone & 1.00 & 0.60 & 1.00 & 1.50 & 1.50 \\
Dicalcium phosphate & 0.40 & 0.30 & 0.40 & 0.50 & 0.50 \\
L-Lysine & 0.05 & 0.05 & 0.05 & 0.05 & 0.05 \\
DL Methionine & 0.16 & 0.16 & 0.16 & 0.16 & 0.16 \\
Vit-min premix & 0.25 & 0.25 & 0.25 & 0.25 & 0.25 \\
Coccidiostat & 0.02 & 0.02 & 0.02 & 0.02 & 0.02 \\
Common salt & 0.25 & 0.25 & 0.25 & 0.25 & 0.25 \\
\hline Total & 100 & 100 & 100 & 100 & 100 \\
\hline Estimated nutrient composition & \multicolumn{5}{c}{} \\
ME (kcal/kg) & 2933.23 & 3058.85 & 3052.96 & 3055.58 & 3062.14 \\
CP (\%) & 20.37 & 20.02 & 20.30 & 20.01 & 20.05 \\
EE (\%) & 3.00 & 2.91 & 2.93 & 2.95 & 3.22 \\
\hline
\end{tabular}

${ }^{\#} \mathrm{~T}_{\mathrm{o}}=0 \%$ palm oil, $\mathrm{T}_{1}=2 \%$ palm oil, $\mathrm{T}_{2}=3 \%$ palm oil, $\mathrm{T}_{3}=4 \%$ palm oil and $\mathrm{T}_{4}=5 \%$ palm oil, included feed 
Bang. J. Anim. Sci. 2010, 39(1\&2)

\section{Results and Discussion}

\section{Feed consumption}

Weekly average and cumulative feed consumption of broilers in different dietary groups is presented in Table 3. Differences in feed consumption among 0, 2, 3, 4 and 5\% palm oil added groups were found highly significant $(\mathrm{P}<0.01)$ at $2^{\text {nd }}$ week of age, while the $5 \%$ dietary palm oil group consumed the lowest amount (333.33g) compared to others. Nwoche et al. (2003) observed the highest $(\mathrm{P}<0.05)$ feed consumption at $4 \%$ inclusion level of palm oil in broiler diet and also found a significant $(\mathrm{P}<0.05)$ depression of feed consumption at $6 \%$ level. Cumulative feed consumption was significantly $(\mathrm{P}<0.05)$ higher in $4 \%$ dietary palm oil group during $4^{\text {th }}$ week but during $5^{\text {th }}$ week feed consumption was the lowest in $5 \%$ oil group. It might be due to higher energy level in the diet as also observed by Franco et al. (1995) and Tawfic and Yo (1989).

Table 3. Feed consumption of broilers in different weeks receiving different dietary levels of palm oil

\begin{tabular}{|c|c|c|c|c|c|c|c|}
\hline \multirow[t]{2}{*}{ Age in week } & \multicolumn{5}{|c|}{ Treatments $^{\#}$} & \multirow[t]{2}{*}{ SED } & \multirow{2}{*}{$\begin{array}{l}\text { Level } \\
\text { of Sig. }\end{array}$} \\
\hline & $\mathbf{T}_{\mathbf{0}}$ & $\mathbf{T}_{2}$ & $\mathbf{T}_{3}$ & $\mathbf{T}_{4}$ & $\mathbf{T}_{5}$ & & \\
\hline $1^{\text {st }}$ & $159 \pm 6.4$ & $152 \pm 0.8$ & $155 \pm 6.5$ & $154 \pm 6.2$ & $144 \pm 4$ & - & NS \\
\hline $2^{\text {nd }}$ & $\begin{array}{c}375.05^{\mathrm{a}} \\
\pm 3.82\end{array}$ & $\begin{array}{l}375.85^{\mathrm{a}} \\
\pm 18.35\end{array}$ & $\begin{array}{l}370.17^{\mathrm{a}} \\
\pm 10.96\end{array}$ & $\begin{array}{l}381.72^{\mathrm{a}} \\
\pm 15.73\end{array}$ & $\begin{array}{c}333.33^{\mathrm{b}} \\
\pm 7.91\end{array}$ & 21.74 & $* *$ \\
\hline $3^{\text {rd }}$ & $675 \pm 11.8$ & $694 \pm 30.1$ & $692 \pm 36.8$ & $692 \pm 38.8$ & $710 \pm 29.6$ & - & NS \\
\hline $4^{\text {th }}$ & $\begin{array}{c}921.01^{\mathrm{bc}} \\
\pm 59.03\end{array}$ & $\begin{array}{c}997.17^{\mathrm{ab}} \\
\pm 51.82\end{array}$ & $\begin{array}{c}1000.62^{\mathrm{ab}} \\
\pm 76.14\end{array}$ & $\begin{array}{c}1035.22^{\mathrm{a}} \pm 38 \\
.71\end{array}$ & $\begin{array}{l}864.67^{\mathrm{c}} \\
\pm 46.46\end{array}$ & 79.06 & $*$ \\
\hline $5^{\text {th }}$ & $1009 \pm 92.3$ & $1081 \pm 63.5$ & $1069 \pm 45.1$ & $1119 \pm 61.2$ & $1006 \pm 67.4$ & - & NS \\
\hline \multicolumn{8}{|c|}{ Cumulative feed consumption } \\
\hline Initial to $4^{\text {th }}$ & $\begin{array}{c}2130.24^{\mathrm{ab}} \\
\pm 80.85\end{array}$ & $\begin{array}{c}2220.42^{\mathrm{a}} \\
\pm 92.03\end{array}$ & $\begin{array}{c}2218.13^{\mathrm{a}} \\
\pm 92.93\end{array}$ & $\begin{array}{c}2270.54^{\mathrm{a}} \\
\pm 61.77\end{array}$ & $\begin{array}{c}2058.67^{\mathrm{b}} \\
\pm 71.00\end{array}$ & $\begin{array}{c}113 . \\
91\end{array}$ & * \\
\hline Initial to $5^{\text {th }}$ & $3140 \pm 172$. & $3283 \pm 155$ & $3270 \pm 162.5$ & $3390 \pm 108$ & $3064 \pm 112$ & - & NS \\
\hline
\end{tabular}

${ }^{\#} \mathrm{~T}_{\mathrm{o}}=0 \%$ palm oil, $\mathrm{T}_{1}=2 \%$ palm oil, $\mathrm{T}_{2}=3 \%$ palm oil, $\mathrm{T}_{3}=4 \%$ palm oil and $\mathrm{T}_{4}=5 \%$ palm oil, included feed

a,b,c Values sharing uncommon superscripts in the same row are significantly different; Values indicated Mean \pm SE (Standard Error)

SED = Standard Error of Deviation

$* *=$ Significant at $1 \%$ level, * = Significant at 5\% level, NS = Non-significant.

\section{Growth performance}

Weekly weight gain of broilers differed significantly $(P<0.01)$ among the treatment groups at $2^{\text {nd }}$ week of age, where as the highest weight gain (252.73g) was observed in $4 \%$ dietary palm oil group and the weight gain of this group was slightly higher than that of 5, 2 and $0 \%$ dietary oil group at $3^{\text {rd }}$ and $4^{\text {th }}$ week of age (Table 4). From the cumulative weight gain of 
broilers presented in the same table it can be seen that broilers fed on 2, 3 and $4 \%$ palm oil gained higher $(\mathrm{P}>0.05)$ cumulative weight than the control and $5 \%$ oil group. There was an increasing trend of weight gain with increased level of dietary palm oil from $2-4 \%$, which declined at 5\%. However, diet supplemented with higher level of palm oil in replacing of maize resulted non-significant effect on weight gain of broilers (Zulkifli et al., 2003).

Table 4. Live weight gain of broilers receiving different dietary levels of palm oil

\begin{tabular}{|c|c|c|c|c|c|c|c|}
\hline \multirow[t]{2}{*}{ Age in week } & \multicolumn{5}{|c|}{ Treatments $^{\#}$} & \multirow[t]{2}{*}{ SED } & \multirow{2}{*}{$\begin{array}{c}\text { Level of } \\
\text { Sig. }\end{array}$} \\
\hline & $\mathbf{T}_{\mathbf{0}}$ & $\mathbf{T}_{2}$ & $\mathbf{T}_{3}$ & $\mathbf{T}_{4}$ & $\mathbf{T}_{5}$ & & \\
\hline $1^{\text {st }}$ & $93.22 \pm 2.82$ & $96.33 \pm 2.11$ & $102 \pm 6.83$ & $100 \pm 5.92$ & $94.85 \pm 2.8$ & - & NS \\
\hline $2^{\text {nd }}$ & $\begin{array}{c}240.07^{\mathrm{b}} \\
\pm 3.84\end{array}$ & $\begin{array}{c}237.88^{\mathrm{b}} \\
\pm 7.81\end{array}$ & $\begin{array}{c}244.05^{\mathrm{ab}} \\
\pm 10.21\end{array}$ & $\begin{array}{c}252.73^{\mathrm{a}} \\
\pm 5.85\end{array}$ & $\begin{array}{c}223.07^{\mathrm{C}} \\
\pm 1.28\end{array}$ & 3.80 & $* *$ \\
\hline $3^{\text {rd }}$ & $381 \pm 8.88$ & $392 \pm 32.59$ & $397 \pm 14.38$ & $412 \pm 20.29$ & $374 \pm 16.70$ & - & NS \\
\hline $4^{\text {th }}$ & $473 \pm 12.26$ & $486 \pm 70.31$ & $523 \pm 8.96$ & $512 \pm 60.17$ & $497 \pm 23.32$ & - & NS \\
\hline $5^{\text {th }}$ & $477 \pm 54.37$ & $529 \pm 52.63$ & $464 \pm 31.60$ & $465 \pm 7.49$ & $477 \pm 36.18$ & - & NS \\
\hline \multicolumn{8}{|c|}{ Cumulative live weight gain } \\
\hline Initial to $4^{\text {th }}$ & $1188 \pm 25.4$ & $1213 \pm 65.2$ & $1267 \pm 32.9$ & $1278 \pm 51.3$ & $1190 \pm 43.1$ & - & NS \\
\hline Initial to $5^{\text {th }}$ & $1665 \pm 75.4$ & $1743 \pm 78.2$ & $1731 \pm 47.2$ & $1744 \pm 49.4$ & $1667 \pm 67.8$ & - & NS \\
\hline
\end{tabular}

${ }^{\#} \mathrm{~T}_{\mathrm{o}}=0 \%$ palm oil, $\mathrm{T}_{1}=2 \%$ palm oil, $\mathrm{T}_{2}=3 \%$ palm oil, $\mathrm{T}_{3}=4 \%$ palm oil and $\mathrm{T}_{4}=5 \%$ palm oil, included feed a,b,c Values sharing uncommon superscripts in the same row are significantly different $(\mathrm{P}<0.01)$; Values indicated Mean \pm SE (Standard Error)

SED = Standard Error of Deviation

$* *=$ Significant at $1 \%$ level, NS $=$ Non-significant

\section{Cost of production and profit margin}

It was observed that feed cost $(\mathrm{Tk} /$ bird $)$ differed significantly $(\mathrm{P}<0.01)$ among different dietary oil groups (Table 5). Higher costs were observed in the oil supplemented groups compared to that of control group, which is obviously due to the cost of palm oil. The lowest feed cost was observed in $5 \%$ oil group ( $68.60 \mathrm{Tk} / \mathrm{bird})$ than that of others, which might have been due to lower intake of feed due to higher oil level. Total cost per broiler was also found to differ significantly $(\mathrm{P}<0.01)$ among the treatments. Broilers of $4 \%$ oil group were sold at highest price (Tk 197.23/broiler), which was due to the highest average live weight. In spite of achieving the higher sale value of the bird price (Tk/bird) in 2, 3 and $4 \%$ oil group, there was a little variation of profit earned between the former groups and $5 \%$ oil and control group. This might be due to high production cost of these groups (2, 3 and $4 \%$ oil group) compared to control and 5\% oil group. Highest profit margin as observed in terms of per kg bird in control group might also be due to the lowest production cost in this group compared to those of the treated groups. The result obtained from the economic analysis of present study revealed that the use of palm in broiler ration is not cost effective. 
Bang. J. Anim. Sci. 2010, 39(1\&2)

Table 5. Cost of production and profit of the broilers receiving different dietary levels of palm oil

\begin{tabular}{|c|c|c|c|c|c|c|c|}
\hline \multirow[t]{2}{*}{ Parameters } & \multicolumn{5}{|c|}{ Treatments } & \multirow[t]{2}{*}{ SED } & \multirow[t]{2}{*}{ Level of Sig. } \\
\hline & $\mathbf{T}_{\mathbf{0}}$ & $\mathbf{T}_{1}$ & $\mathbf{T}_{2}$ & $\mathbf{T}_{3}$ & $\mathbf{T}_{4}$ & & \\
\hline Chick cost (Tk/chick) & 40.00 & 40.00 & 40.00 & 40.00 & 40.00 & - & NS \\
\hline \multirow[t]{2}{*}{ Feed cost (Tk/kg) } & 20.74 & 22.20 & 22.01 & 21.88 & 21.86 & - & NS \\
\hline & \pm 0.00 & \pm 0.00 & \pm 0.00 & \pm 0.00 & \pm 0.00 & & \\
\hline \multirow[t]{2}{*}{ Feed cost (Tk/kg bird) } & 38.45 & 41.40 & 41.26 & 41.90 & 40.07 & - & NS \\
\hline & \pm 1.35 & \pm 0.70 & \pm 0.87 & \pm 2.09 & \pm 1.45 & & \\
\hline \multirow[t]{2}{*}{ Feed cost (Tk/bird) } & $65.92^{b}$ & $74.15^{\mathrm{a}}$ & $73.3^{\mathrm{a}}$ & $75.05^{\mathrm{a}}$ & $68.60^{b}$ & 4.12 & $* *$ \\
\hline & \pm 2.91 & \pm 3.71 & \pm 1.67 & \pm 1.74 & \pm 0.24 & & \\
\hline \multirow[t]{2}{*}{ Total cost (Tk/kg bird) } & 67.65 & 69.35 & 69.38 & 69.80 & 69.27 & - & NS \\
\hline & \pm 2.27 & \pm 1.25 & \pm 1.41 & \pm 2.86 & \pm 2.60 & & \\
\hline \multirow[t]{2}{*}{ Total cost (Tk/bird) } & $115.92^{\mathrm{b}}$ & $124.15^{\mathrm{a}}$ & $123.3^{\mathrm{a}}$ & $125.0^{\mathrm{a}}$ & $118.6^{\mathrm{b}}$ & 4.12 & $* *$ \\
\hline & \pm 2.91 & \pm 3.71 & \pm 1.67 & \pm 1.74 & \pm 0.24 & & \\
\hline${ }^{\S}$ Miscellaneous cost (Tk/bird) & 10.00 & 10.00 & 10.00 & 10.00 & 10.00 & - & NS \\
\hline Sale (Tk/bird) & $188 \pm 8.3$ & $197 \pm 8.6$ & $195 \pm 5.1$ & $197 \pm 5.5$ & $188 \pm 7$ & - & NS \\
\hline \multirow[t]{2}{*}{ Profit (Tk/bird) } & 72.73 & 72.86 & 72.31 & 72.18 & 69.81 & - & NS \\
\hline & \pm 8.38 & \pm 8.61 & \pm 5.14 & \pm 5.55 & \pm 7.60 & & \\
\hline \multirow[t]{2}{*}{ Profit (Tk/kg bird) } & 42.35 & 40.65 & 40.62 & 40.20 & 40.73 & - & NS \\
\hline & \pm 2.27 & \pm 1.25 & \pm 1.41 & \pm 2.86 & \pm 2.60 & & \\
\hline
\end{tabular}

${ }^{\#} \mathrm{~T}_{\mathrm{o}}=0 \%$ palm oil, $\mathrm{T}_{1}=2 \%$ palm oil, $\mathrm{T}_{2}=3 \%$ palm oil, $\mathrm{T}_{3}=4 \%$ palm oil and $\mathrm{T}_{4}=5 \%$ palm oil, included feed

${ }^{\mathrm{a}, \mathrm{b}}$ Values sharing uncommon superscripts in the same row are significantly different; Values indicated Mean \pm SE (Standard Error)

SED (Standard Error of Deviation)

** = Significant at $1 \%$ level, NS = Non-significant; ${ }^{\S}=$ vaccination and medication, litter, repairing cost.

\section{Conclusion}

The inclusion of $4 \%$ palm oil in broiler diets resulted in better growth performance, feed consumption and FCR compared to those of control and other levels of supplementations. But the profit obtained from the control group was higher compared to that of all oil supplemented groups. Therefore, it can be concluded from the present finding that for profitable broiler production supplementation of palm oil as energy source is not essential.

\section{Literature Cited}

Anigbogu, N. M. 2001. Performance efficiency of broiler chicks fed diets with different levels of palm oil and tannia tuber meal. J. Appl. Chem. Agril Res., 7: 1-16. 
Franco, S. G., Junqueira, O. M., Fedalto, L. M. and Paulillo, A. C. 1995. Effects of feeding programs and the addition of oil, in different phases, on the development of broiler chickens. Revista-doSetor-de-Ciencias-Agrarias, 14: 95 - 102.

McNab, J. 1999. Advances in poultry nutrition in the world. In: Proceedings of the Seminar and International Poultry Show. World Poultry Science Association - Bangladesh Branch, p. 52.

Nwoche, G. N., Ndubuisi, E. C. and Iheukwumere, F. C. 2003. Effects of dietary palm oil on the performance of broiler chicks. Intl. J. Ag. Rural Develop., 4: 81-86.

Pesti, G. M., Bakalli, R.I., Qiao, M. and Sterling, K.G. 2002. A comparison of 8 grades of fat as broiler feed ingredients. Poult. Sci., 81: 382-390.

Reginatto, M. F., Ribeiro, A. M. L., Penz, A. M., Kessler, A. M. and Krabbe, E. L. 2000. Effect of energy, energy: protein ratio and growing phase on the performance and carcass composition of broilers. Revista Brasileira de Ciencia Avicola, 2: 229-237.

Renner, R. and Hill, F. W. 1991. Factors affecting the absorbability of saturated fatty acids in the chick. J. Nutr., 74: 254-258.

Tawfik, E. S. and Yo, T. 1989. Influence of dietary energy density on feed intake, feed efficiency and weight gain of broilers. Poult. Abst., 16: 757.

Zulkifli, I., Ginsos, J., Liew, P. K. and Gilbert, J. 2003. Growth performance and Newcastle disease antibody titres of broiler chickens fed palm-based diets and their response to heat stress during fasting. Archiv-fur-Geflugelkunde, 67: 125-130. 